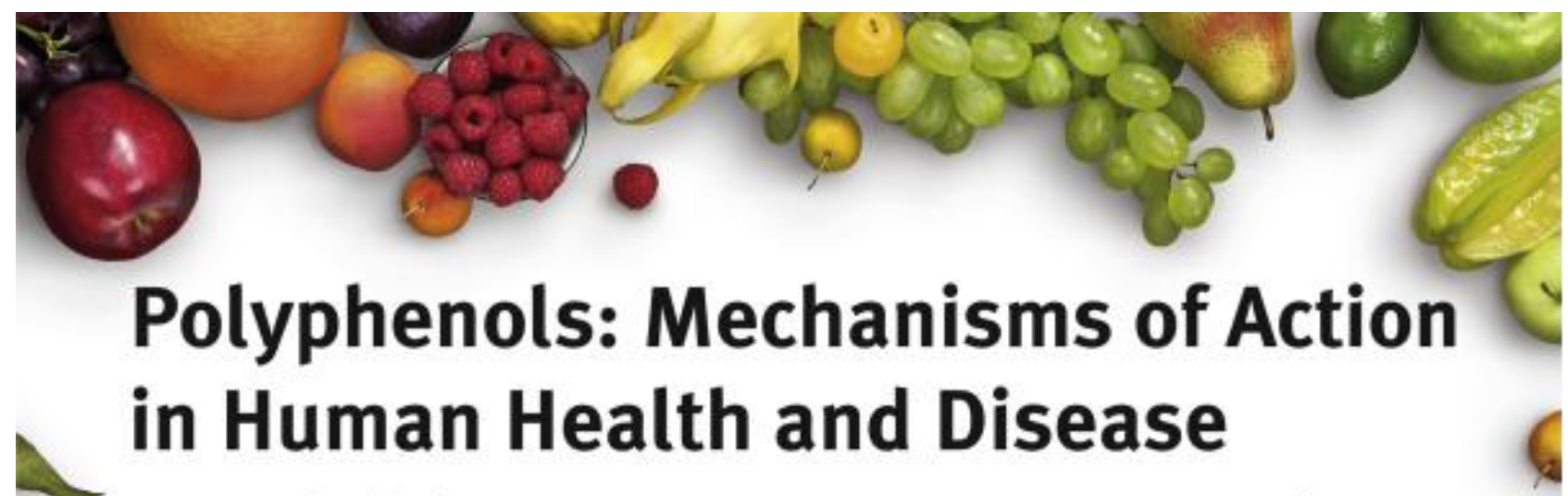

Second Edition

Volume 1

Edited by

Ronald Ross Watson

Victor R. Preedy

Sherma Zibadi
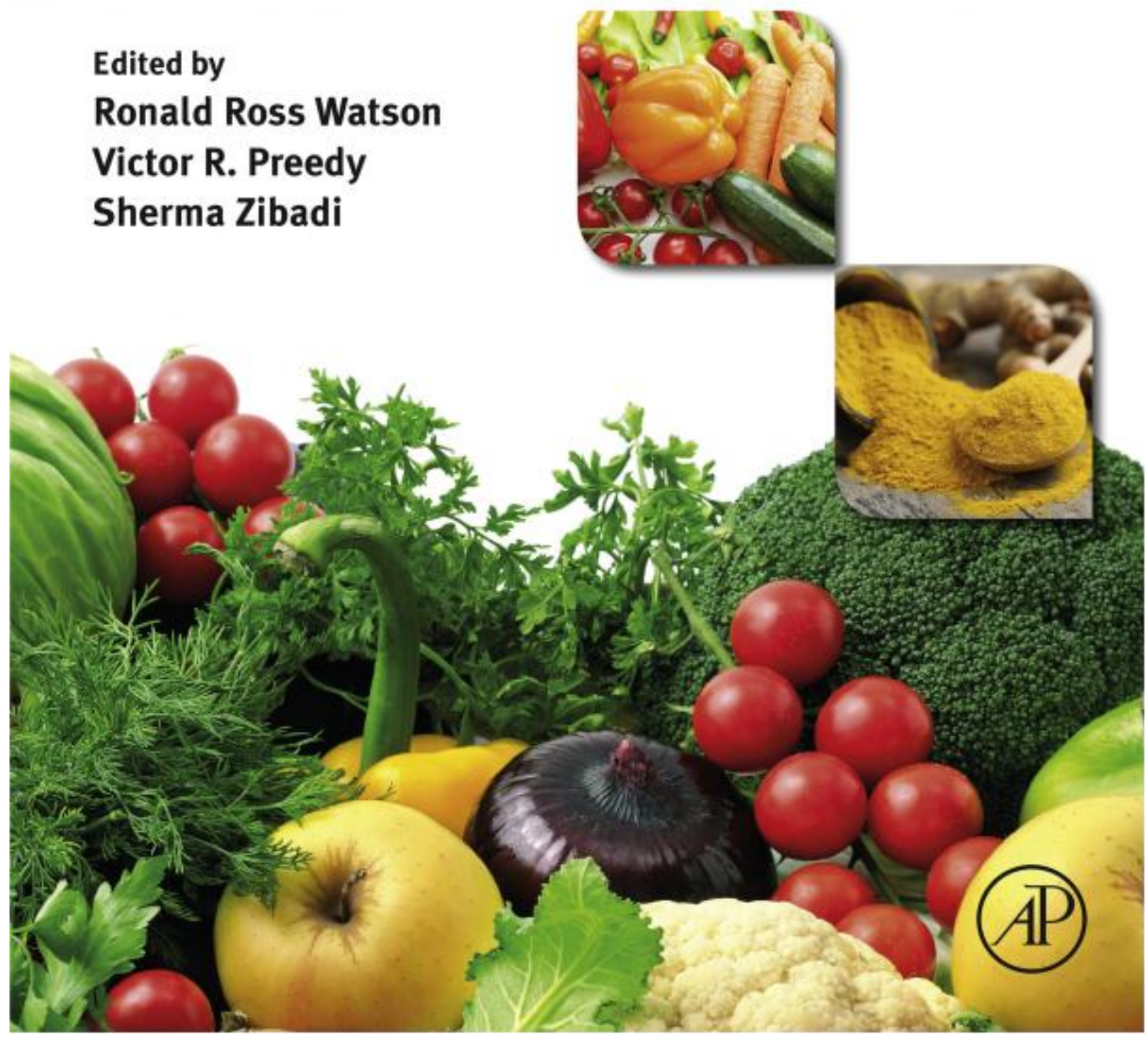


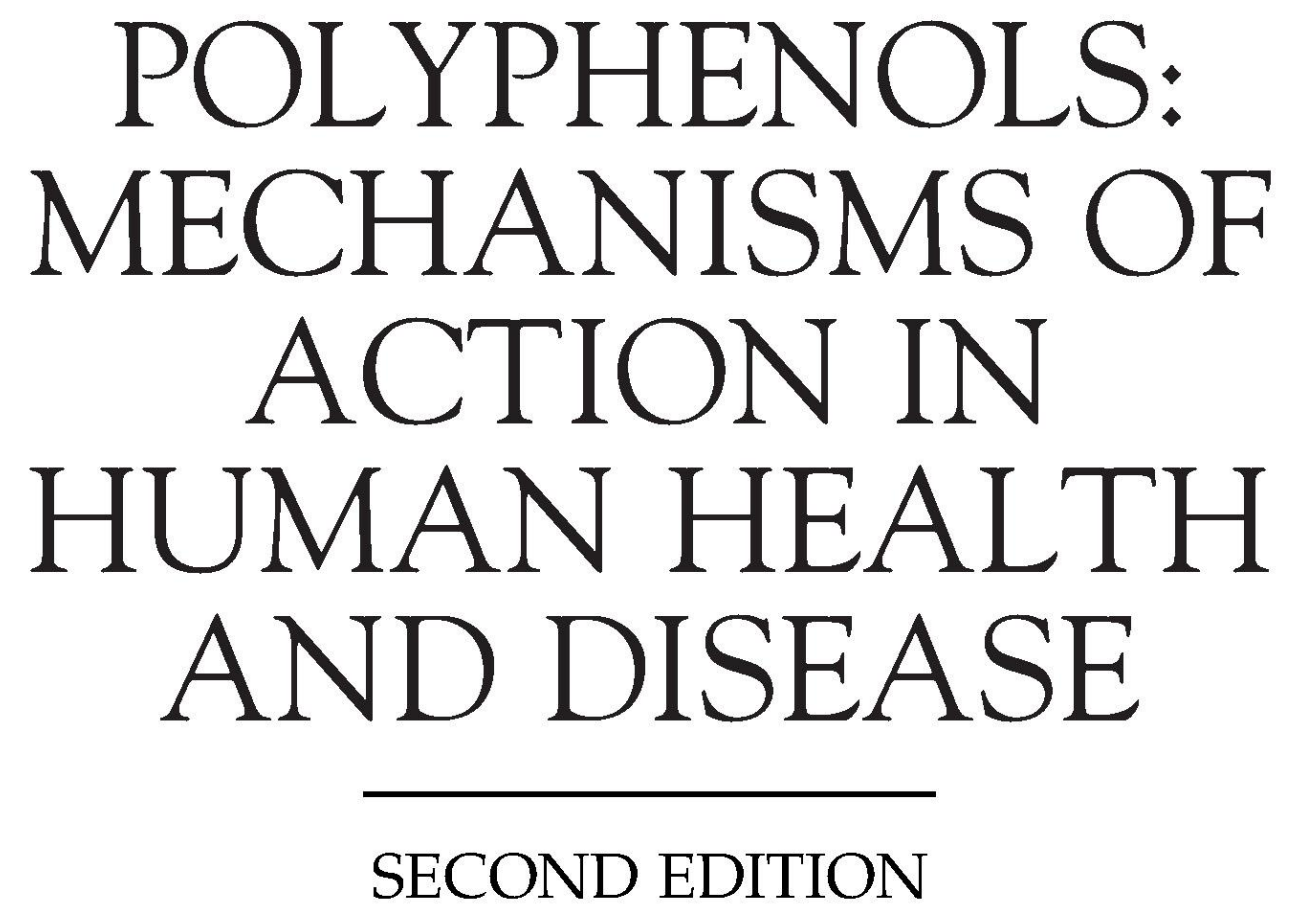

Volume 1

\author{
Edited By \\ RONALD Ross WATSON \\ Victor R. Preedy \\ Sherma Zibadi
}

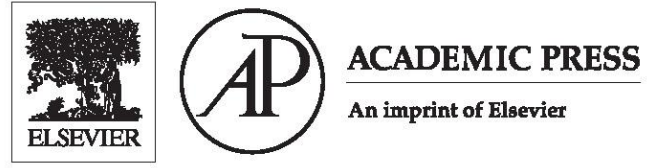


Academic Press is an imprint of Elsevier

125 London Wall, London EC2Y 5AS, United Kingdom

525 B Street, Suite 1650, San Diego, CA 92101, United States

50 Hampshire Street, 5th Floor, Cambridge, MA 02139, United States

The Boulevard, Langford Lane, Kidlington, Oxford OX5 1GB, United Kingdom

(C) 2018 Elsevier Inc. All rights reserved.

No part of this publication may be reproduced or transmitted in any form or by any means, electronic or mechanical, including photocopying, recording, or any information storage and retrieval system, without permission in writing from the publisher. Details on how to seek permission, further information about the Publisher's permissions policies and our arrangements with organizations such as the Copyright Clearance Center and the Copyright Licensing Agency, can be found at our website: www.elsevier.com/permissions.

This book and the individual contributions contained in it are protected under copyright by the Publisher (other than as may be noted herein).

Notices

Knowledge and best practice in this field are constantly changing. As new research and experience broaden our understanding, changes in research methods, professional practices, or medical treatment may become necessary.

Practitioners and researchers must always rely on their own experience and knowledge in evaluating and using any information, methods, compounds, or experiments described herein. In using such information or methods they should be mindful of their own safety and the safety of others, including parties for whom they have a professional responsibility.

To the fullest extent of the law, neither the Publisher nor the authors, contributors, or editors, assume any liability for any injury and/or damage to persons or property as a matter of products liability, negligence or otherwise, or from any use or operation of any methods, products, instructions, or ideas contained in the material herein.

Library of Congress Cataloging-in-Publication Data

A catalog record for this book is available from the Library of Congress

British Library Cataloguing-in-Publication Data

A catalogue record for this book is available from the British Library

ISBN 978-0-12-813006-3

For information on all Academic Press publications visit our website at https://www.elsevier.com/books-and-journals

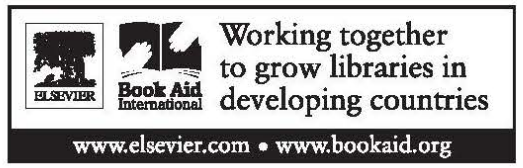

Acquisition Editor: Tari Broderick Editorial Project Manager: Pat Gonzalez

Production Project Manager: Punithavathy Govindaradjane

Cover Designer: Mark Rogers

Typeset by SPi Global, India 


\section{Contents}

\author{
Contributors \\ Preface \\ Acknowledgments
}

$\begin{array}{rll}\text { xi } & 3 \text { Styles } & 20 \\ \text { xv } & 4 \text { Ingredients } & 21 \\ \text { xvii } & 5 \text { Health Benefits of Beer Polyphenols: Xanthohumol } & 23 \\ & 6 \text { Summary } & 29 \\ & \text { References } & 30 \\ & \text { Glossary } & 32\end{array}$

4. Polyphenolic Flavonoids and Metalloprotease Inhibition: Applications to Health and Disease DEJAN AGIĆ, MARIJA ABRAMIĆ, VESNA RASTIJA, ROSEMARY VUKOVIĆ

1. Polyphenols in the Prevention of Acute Pancreatitis in Preclinical Systems of Study: A Revisit ELROY SALDANHA, SURESH RAO, MOHAMMED ADNAN, MICHAEL L.J. PAIS, TARESH SHEKAR NAIK, RITESH D'CUNHA, RESHMINA D'SOUZA, MANJESHWAR SHRINATH BALIGA

1 Introduction

2 Curcumin

3 Resveratrol

4 Quercetin

5 Genistein

6 Ellagic Acid

7 Cinnamtannin B-1

8 Green Tea Polyphenols

9 Conclusions and Future Directions

References

Further Reading

2. Polyphenols as Supplements in Foods and Beverages: Recent Discoveries and Health Benefits, an Update

ANDRÉA PITTELLI BOLAGO GOLLÜCKE, ROGÉRIO CORREA PERES, DANIEL ARAKI RIBEIRO, ODAIR AGUIAR

1 Polyphenols and Supplementation

2 New Insights on Polyphenol Metabolism and Action

3 Benefits of Polyphenol's Consumption: Experimental Data

4 Antimicrobial Activity of Polyphenols

5 Noxious Activities Induced by Polyphenols: An Intriguing Issue

6 Concluding Remarks and Future Challenges

References

3. Xanthohumol and the Medicinal Benefits of Beer

SUSAN M. ELROD

1 Introduction

2 History of Beer and Brewing
1 Introduction

2 Matrix Metalloproteinases

33 Angiotensin-Converting Enzyme

4 Conclusion

References

33

34

36

38

5. Biological and Pharmacological Effects of Polyphenolic Compounds From Ecklonia cava AKIKO KOJIMA-YUASA.

1 Introduction

2 Biological and Pharmacological Effects of

Phlorotannins From E. cava

3 Protective Effect Against Ethanol-Induced Liver Injury

4 AMPK in the Protective Effects of Phlorotannins

5 Conclusion

References

41

41

47

49

50

6. Clerodendrum volubile: Phenolics and

Applications to Health

Introduction

2 Phenolics and Health

53

3 Phytochemistry of Clerodendrum volubile

1

12

13

14

4 Biological Activities of Clerodendrum volubile

5 Proposed Mechanism of Action of C. volubile

6 Conclusion

Acknowledgments

References

16 7. Eryngium campestre L.: Polyphenolic and Flavonoid Compounds; Applications to Health and Disease

19 BOUZIDI SOUMIA

1 Introduction

192 About the Plant

193 Distribution
11 OCHUKO L. ERUKAINURE, OLAKUNLE SANNI, MD. SHAHIDUL ISLAM 


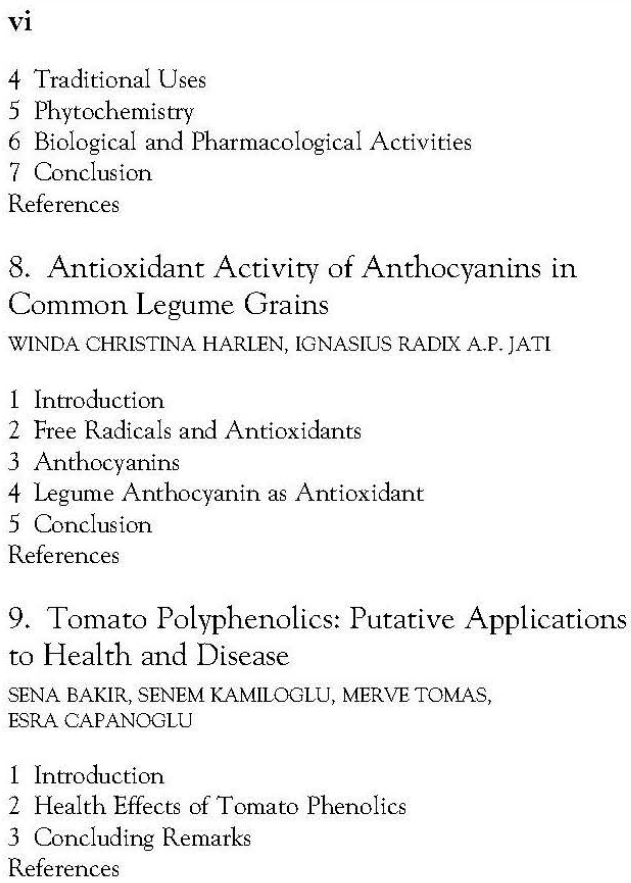

8. Antioxidant Activity of Anthocyanins in Common Legume Grains

WINDA CHRISTINA HARLEN, IGNASIUS RADIX A.P. JATI

1 Introduction

2 Free Radicals and Antioxidants

3 Anthocyanins

4 Legume Anthocyanin as Antioxidant

5 Conclusion

References

9. Tomato Polyphenolics: Putative Applications to Health and Disease

SENA BAKIR, SENEM KAMILOGLU, MERVE TOMAS, ESRA CAPANOGLU

1 Introduction

2 Health Effects of Tomato Phenolics

3 Concluding Remarks

References

10. Polyphenolic Compounds in Sweet Cherries: A Focus on Anthocyanins

KATHERINE KENT, NADINE HÖLZEL, NIGEL SWARTS

1 An Overview of the Nutritive and Nonnutritive Properties of Sweet Cherries

2 A Focus on Anthocyanins in Sweet Cherries

3 Anthocyanin Biosynthesis in Sweet Cherries

4 Measurement of Anthocyanin Content in Sweet Cherrie

5 Pre- and Postharvest Factors That Impact on

Anthocyanins in Sweet Cherries

6 Patterns of Global Growth and Economic Importance of Sweet Cherry Production

7 Important Sensory Attributes and Traditional

Quality Indicators of Sweet Cherries

8 Consumer Preference for Sweet Cherries May Not Be Driven by Health

9 Sweet Cherry Consumption and Contribution to Habitual Anthocyanin Consumption

10 Sweet Cherries and Health Outcomes: Potential Mechanisms of Action

11 Conclusion: Major Gaps in Literature and Future Research Direction

Acknowledgments

References

11. Citrus Fruit Polyphenols and Flavonoids: Applications to Psychiatric Disorders MARLA ROSARIA ANNA MUSCATELLO, ROCCO ANTONIO ZOCCALI, ANTONIO BRUNO

1 Introduction

2 The Global Burden of Mental Illness

CONTENTS

703 Moving Toward Integrative Prevention and Care: The Link

Between Nutrition and Mental Health 120

4 Citrus Polyphenols and Flavonoids 121

5 Citrus Polyphenols in Mental Disorders 123

6 Conclusions and Future Directions 128

References

81

81

81

82

82

90

90

2 Chemical Properties of Anthocyanins

II

\section{POLYPHENOLS IN THERAPY OF OBESITY AND DIABETES}

12. Anthocyanins and Diabetes Regulation

HONGHUI GUO, MIN XIA

3 Dietary Anthocyanin Source

4 Anthocyanin Bioavailability

5 Antidiabetic Effects of Anthocyanins and the Underlying Mechanisms

6 Conclusion and Perspective $\quad 142$

Acknowledgments 143

References

13. The Role of Direct and Indirect Polyphenolic Antioxidants in Protection Against Oxidative

Stress

LARS PORSKJAR CHRISTENSEN

1 Introduction

2 Cytoprotective Proteins (Phase 2 Enzymes)

4 Direct and Indirect Antioxidants and Their Role in Protection Against Oxidative Stress

5 Polyphenol and Polyphenol-Derived Inducers of Cytoprotective Proteins (Indirect Antioxidant Effect) 152

6 Conclusions

References

109

14. Role of Protocatechuic Acid in

110 Obesity-Related Pathologies: An Update

181

MASSIMO D'ARCHIVIO, BEATRICE SCAZZOCCHIO

111 ANNALISA SILENZI, CLAUDIO GIOVANNINI, ROBERTA MASELLA

1121 Introduction

2 Protocatechuic Acid: Food Content and Bioavailability

181

1153 Obesity: A Global Challenge Yet Today

1164 Mechanism of Action of PCA

1165 Conclusion

References

119 15. Exposure to Polyphenolic Compounds Modulates Type 1 Diabetes: The Case of Genistein 193 GUANNAN HUANG, JOELLA XU, TAI L. GUO

1191 Introduction

1192 Pathogenesis of T1D 
4 Mechanisms of T1D Modulation by Polyphenolic

Compounds: Gut Microbiota

5 Mechanisms of T1D Modulation by Polyphenolic Compounds: Epigenetics

6 Other Potential Mechanisms

7 Conclusion

Acknowledgments and Funding Support

References
3 Polyphenolic Compounds and T1D

1947 Future Direction $\quad 244$

8 Concluding Remarks 245

196 References 245

199 19. Possible Benefits and Risks of Polyphenols

200 Supplementation During Pregnancy

ANTONIO GONZALEZ-BULNES, SUSANA ASTIZ,

BEATRIZ ISABEL, MARTA VAZQUEZ-GOMEZ,

CONSOLACION GARCLA-CONTRERAS

\section{III}

Outline

1 Introduction

The Role of Intrauterine Environment in Pregnancy Development

3 The Role of the Intrauterine Environment in Postnatal Traits

5 Alternative Tools for Prevention and Treatment

16. Chocolate/Cocoa Polyphenols and Oxidative Stress

JUDTH E ALLGROVE, GLEN DAVISON of IUGR: Amino Acids and Antioxidants

Implications and Evidence for Beneficial Effects of Polyphenols Supplementation During Pregnancy

1 Introduction

2 Antioxidant Properties

3 Bioavailability

4 Research on Cocoa and Oxidative Stress

5 Summary

References

7 Possible Risks of Polyphenols Supplementation During Pregnancy

8 Concluding Remarks and Future Research $\quad 256$

Acknowledgments 256

References

20. Flavonoids as Modulators of Neutrophils'

Oxidative Burst: Structure-Activity

17. An Overview of Dietary Polyphenols and Their Therapeutic Effects

221 Relationship

DANIELA RIBEIRO, EDUARDA FERNANDES, MARISA FREITAS

PAULAVI KESAVAN, ANTARA BANERJEE ANUSHKA BANERJEE RAMACHANDRAN MURUGESAN, FRANCESCO MAROTTA, SURAJIT PATHAK

1 Introduction

2 Structural Classification of Polyphenols

3 Dietary Intake and Content of Polyphenols

4 Bioavailability and Distribution of Polyphenols

5 Epigenetic Modifications and Polyphenol

Metabolism

6 Nutritional Genomics and Dietary Polyphenols

7 Novel Therapeutics Using Polyphenols

Acknowledgments

References

Further Reading

1 Introduction

2 Neutrophils Morphology 261

3 Neutrophil Phagocytosis 262

4 Production of Reactive Oxygen Species 262

5 Production of Reactive Nitrogen Species 264

6 Flavonoids 265

7 Effect of Flavonoids on Neutrophils' Oxidative Burst 266

8 Catechol Group in the B-Ring 272

9 3-OH in the C-Ring 273

10 C2-C3 Double Bond 274

11 Conclusion $\quad 274$

Acknowledgments $\quad 274$

References $\quad 274$

21. Manipulation of Mitochondrial Function by Polyphenols for New Treatment Strategies

Attenuates Pain: Neurophysiological

Mechanisms

MAMORU TAKEDA, SHIORI TAKEHANA, YOSHIHITO SHIMAZU

1 Introduction

2 Classification of Pain

3 Pain Pathway in the Trigeminal System

4 Modulatory Mechanism of Resveratrol on the

Nociceptive Pain

5 Modulatory Mechanism Underlying the Effect of Resveratrol on Pathological Pain

6 Functional Significance for Modulation of Pain Relief
237 CORINA. T. MADREITER-SOKOLOWSKI, WOLFGANG F. GRAIER

1 Introduction

2372 Mitochondria

2383 Polyphenols 280

2384 Manipulation of Mitochondrial Function by

Polyphenols

2395 Polyphenols as Treatment Strategies to Manipulate

Mitochondrial (Dys)Function in Diseases

2416 Conclusion

References

243 Glossary

(1)

\section{9}

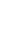

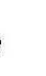

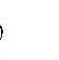

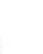

56

a

1

2

4

.

4

\section{nn}




\section{IV \\ BIOAVAILABILITY AND EFFECTS ON METABOLISM}

22. Bioavailability of Flavonoids: The Role of Cell Membrane Transporters

JOVANA ČVOROVIĆ, LOVRO ZIBERNA, STEFANO FORNASARO FEDERICA TRAMER, SABINA PASSAMONTI

1 Introduction

2 Principles of Membrane Transport

3 Indirect Evidence Supporting the Existence of Flavonoid

Membrane Transporter

4 Anatomical Distribution of Flavonoid-Related Membrane Transporters

5 Issues Related to the Low Bioavailability of Flavonoids

6 Transporter-Based Flavonoid-Drug Interactions

7 Conclusion

Acknowledgments

References

23. Interaction of Polyphenols With the Intestinal and Placental Absorption of Some Bioactive Compounds

ELISA KEATING, CONCEIÇÄO CALHAU, ANA FARLA, FÁTIMA MARTEL

1 Introduction

2 Effect of Polyphenols on the Transport of 1-Methyl-4-

Phenylpyridinium

3 Effect of Polyphenols on the Transport of Folates

4 Effect of Polyphenols on the Transport of Thiamine

5 Effect of Polyphenols on the Transport of Glucose

6 Conclusions

References

24. Analyzing Ingredients in Dietary Supplements and Their Metabolites

JEEVAN K. PRASAIN, STEPHEN BARNES, J. MICHAEL WYSS

1 Introduction

2 Anthocyanins

3 Flavanols

4 Flavones and Flavonols

5 Isoflavones

6 Extraction of Isoflavones

7 In Vivo Metabolism of Isoflavones

8 Conclusions

References

25. Metabolism of Dietary Polyphenols by Human Gut Microbiota and Their Health Benefits

SURAJIT PATHAK, PALLAVI KESAVAN, ANUSHKA BANERJEE, ANTARA BANERJEE, GULCIN SAGDICOGLU CELEP, LAURA BISSI, FRANCESCO MAROTTA

1 Introduction

2 Dietary Intake of Polyphenols

3 Absorption, Metabolism, and Bioavailability of Polyphenols

4 Metabolism of Polyphenols by the Gut Microbiota 350

5 Enzymes in the Metabolism of Polyphenols 353

6 Modulation of Gut Microbiota by Polyphenols 353

7 Health Benefits of Polyphenols and Their Microbial Metabolites

8 Conclusions

354

355

Acknowledgments 356

References

26. Bioavailability and Biochemistry of Quercetin and Applications to Health and Diseases

GABRIELE CARULLO, MARLATERESA BADOLATO,

1 Chemical Features of Quercetin

2 Bioavailability, Absorption and Metabolism of Quercetin

3 Mechanistic and Preclinical Studies of Quercetin and Its Metabolites

4 Esters of Quercetin and Their Therapeutic Applications

5 Conclusion

References

Further Reading

321 27. Effects of Quercetin and Its Combinations on Health

S.K. SHEBEKO, I.A. ZUPANETS, O.S. POPOV, O.O. TARASENKO,

321

S. SHALAMAY

1 Introduction

Basic Pharmacological Properties of Quercetin

3 Pharmacokinetic Properties of Quercetin and Ways of Modifying Them

5 Angioprotective Activity of Quercetin 379

6 Effects of Quercetin on Hemostasis 379

7 Cardioprotective Properties of Quercetin 380

8 Application of Quercetin-Based Drugs in Chronic Kidney Disease

9 Quercetin-Based Drugs in Joint Diseases

10 Conclusion

References

28. Green Tea Polyphenols in the Amelioration of Osteoarthritis: Memoir on the Preclinical Observations

NAVEEN JOSEPH MATHAI, DAVANAGERE MURALI SUJAYENDRA,

347 MOHAMMED ADNAN, TARESH SHEKAR NAIK, THOMAS GEORGE, SONIYA ABRAHAM, MANJESHWAR SHRINATH BALIGA

1 Introduction

2 Green Tea in Arthritis 
5 Free Radical Scavenging and Antioxidant Properties 6 Green Tea Increases Antioxidant Enzymes and Reduces Lipid Peroxidation

7 Antiinflammatory Effects

8 Green Tea Polyphenols Inhibit the Activation of Mitogen-Activated Protein Kinases

9 Green Tea and Its Polyphenols Decrease Activation of NF- $\mathrm{NB}$

10 EGCG and Its Influence on Matrix Metalloproteinases

11 Chondroprotective Effects of EGCG

12 EGCG Inhibits Osteoclast Activation and Differentiation

13 Conclusion

References

29. Polyphenolics Evoke Healing Responses: Clinical Evidence and Role of Predictive Biomarkers

RUSSELL JAFFE, JAYASHREE MANI

1 Polyphenolic Consumption

2 Flavanoids and Flavonols

3 Measurements of Antioxidant Capacity

4 Quercetins

5 Synergistic Polyphenols: Quercetin Dihydrate and

Soluble Orthoproanthocyanidin

6 Orthoproanthocyanidins (Soluble OPCs)

7 Ellagic Acid Content: Pomegranate Juice

8 Clinical Considerations: Whole Fruit and Fruit Juice

9 Predictive Biomarkers Referenced to Goal Values:

Personalized Care

10 Conclusions

References

30. Hepatoprotective Effects of Green Tea and Its Polyphenols: A Revisit

MANJESHWAR SHRINATH BALIGA, ARNADI RAMACHANDRAYYA SHIVASHANKARA, PAUL SIMON, SURESH RAO, PRINCY LOUIS

PALATTY

1 Introduction

2 Tea Protects Against Alcohol-Induced Hepatotoxicity

3 Tea Protects Against Carbon Tetrachloride-Induced

Hepatotoxicity

4 Effect of Tea on $N$-Acetaminophen-Induced

Hepatotoxicity

5 Tea Is Effective in Viral Hepatitis

6 Effect of Tea on Ischemia Reperfusion Injury
3997 Effect of Green Tea Phytochemicals on Hepatotoxicity of Lead

399

399

8 Effect of Tea Phytochemicals on Hepatotoxicity of Azathioprine

9 Effect of Tea Phytochemicals on Galactosamine-Induced Liver Damage

10 Effect of Tea Phytochemicals on LipopolysaccharideInduced Liver Damage

11 Effect of Tea Phytochemicals on Fumonisin B1-Induced Liver Damage

12 Effect of Tea on Hepatotoxicity of Aflatoxins

13 Effect of Tea Phytochemicals on Phenobarbitol-Induced Liver Damage

14 Effect of Tea on Hepatocarcinogenesis

15 Effect of Tea Polyphenols on Fatty Liver Disease

16 Effect of Tea Polyphenols on Obesity-Induced Liver Damage

403

17 Conclusions

References

418

31. CAPE and Tympanosclerosis

IBRAHIM AĞRI, ARZU ERDAL AĞRI, DOĞUKAN ÖZDEMIR, ABDULKADIR ÖZGÜR

1 The Effect of Caffeic Acid Penethyl Ester on

Tympanosclerosis

421

2 Caffeic Acid Phenethyl Ester 421

3 CAPE and Oxidative Stress $\quad 422$

4 CAPE and Inflammation 423

5 Tympanosclerosis 423

6 CAPE and Tympanosclerosis $\quad 427$

References $\quad 428$

Further Reading 430

32. The Polyphenolic Compound Hesperidin

and Bone Protection

431

JENALYN L. YUMOL, WENDY E. WARD

1 Introduction

2 Nutrition as a Strategy for Maintaining Healthy, Strong Bones

415
415

3 Hesperidin Consumption and Its Effect on Outcomes of Bone Protection

4 Summary

References

433

438

438

416

417

417 Index 


\title{
Antioxidant Activity of Anthocyanins in Common Legume Grains
}

\author{
Winda Christina Harlen, Ignasius Radix A.P. Jati \\ Widya Mandala Catholic University Surabaya, Surabaya, Indonesia
}

\author{
Acronym and Abbreviation \\ ABTS 2,2'-azino-bis(3-ethylbenzothiazoline-6-sulphonic acid) \\ DNA deoxyribonucleic acid \\ DPPH 2,2-diphenyl-1-picrylhydrazyl \\ FAO Food and Agriculture Organization \\ GAE gallic acid equivalent \\ GPx glutathione peroxidase \\ MDA malondialdehyde \\ NADPH nicotinamide adenine dinucleotide phosphate \\ SOD superoxide dismutase \\ TBARS thiobarbituric acid reactive substances \\ USDA The United States Department of Agriculture
}

\section{INTRODUCTION}

Legumes have long been consumed as rich sources of protein in human diets all over the world. Usually, people consume legumes in various cooked forms (boiled, fermented, fried) and they are served as either main or side dishes. In addition, legumes are also popular to be eaten as a snack (e.g., peanuts, soybeans) in many Asian and African countries. Legumes are plants belonging to the family Leguminoceae. Among many, soybean, peanut, pea, common bean, lentil, lupin, mesquite, carob, alfalfa, and clover are several examples of the best-known and most-consumed legumes in the world.

Recently, recommendations to increase the consumption of legumes have been widely promoted based on many chemical, biochemical, clinical, and epidemiological studies which show that there are positive correlations between consuming legumes and decreasing the incidence of various degenerative diseases, such as cancer, diabetes, coronary heart disease, and obesity. The ability of legumes to reduce the incidence of such diseases is believed to be attributed to biologically active compounds in legume grains. Among others, phenolic constituents including anthocyanins have been deeply explored in relation to their health-promoting properties. Therefore, in addition to their high nutrient profile, legumes are also rich sources of bioactive compounds, especially phenolics; recent research studies are comprehensively focusing on the role of phenolic constituents such as anthocyanin as antioxidants in human diet and their role in promoting human health, as well as in preventing the incidence of various diseases.

The increased rate of degenerative diseases has been investigated by numerous researchers who have suggested that factors such as unhealthy lifestyle, unbalanced diet patterns, and pollution are responsible as the trigger for incidence of degenerative diseases. One of these diseases is coronary heart disease, which is seen as the number one killer in the world. Changes in diet patterns, with more vegetables and legumes and less meat, are believed to have a favorable impact on human health and could decrease the risk of coronary heart disease, as well as other diseases.

\section{FREE RADICALS AND ANTIOXIDANTS}

The ability of legume grains to decrease the rate of disease or to promote human health is believed to be a result of a synergical effect between the nutrient content, which is rich in proteins and low in fat, with the bioactive compounds found in legumes, such as phenolics and anthocyanin. Bioactive compounds in legume grains play an important role as antioxidants or free radical scavenging compounds, which could balance the number of free radicals in the human system. 
Free radicals are molecules with unpaired electrons and are very reactive in nature. Therefore, they can damage surrounding molecules. In the human system, lipid, protein, DNA, and carbohydrate are molecules susceptible to attack by free radicals, resulting in diseases such as atherosclerosis, coronary heart disease, and cancer. In the normal condition, a certain level of free radicals is found everywhere in the human body, produced as the result of metabolic processes. Free radicals are also useful because they play a role in several biological processesfor example, the phagocytic work by white blood cellsand also they are believed to act as a cellular messenger in a biological process called redox signaling. However, unhealthy lifestyle and diet are believed to create an excessive number of free radicals. The free radical will initiate a chain reaction of the oxidation process, which causes damage to macromolecules. Degenerative diseases are believed to be a result of such severe oxidative stress.

Antioxidants are therefore needed to balance the number of free radicals in the human system, thus preventing damage to macromolecules due to oxidative stress. An antioxidant is any substance that has the ability to inhibit the oxidation of other molecules when present in low concentrations. The human defense system actually produces its own antioxidant substances, which are called endogenous antioxidants, in the form of enzymes (superoxide dismutases, catalase, glutathione peroxidase) and nonenzyme antioxidants (alpha lipoic acid, coenzyme Q10, metal-binding proteins). However, under abnor$\mathrm{mal} /$ diseased conditions, the number of free radicals exceeds the production of antioxidants in the human system. Thus the body needs the intake of exogenous antioxidants from the diet. Enhancing the antioxidant capacity of the human system by optimizing the dietary intake of natural antioxidants is one of the best strategies to balance between free radical and antioxidant activity in the human system.

\section{ANTHOCYANINS}

Among many antioxidant compounds found in legume grains, anthocyanins are a bioactive compound that has been widely investigated due to its ability to scavenge free radicals and also to chelate metal due to its chemical structure. Therefore, anthocyanin also possesses a strong inhibitory effect against lipid oxidation [1]. Anthocyanins are representative of a wide group of flavonoids and are derivatives of 2-phenylbenzopyrylium, which is responsible for the attractive colors (blue, violet, purple, and even black) of the plant parts, including flowers, fruits, vegetables, and seeds [2]. Various food products of fruit and vegetable origin are the major sources of anthocyanin compounds. Anthocyanins can also be found in legumes that have black, purple, blue, and red color, for example,

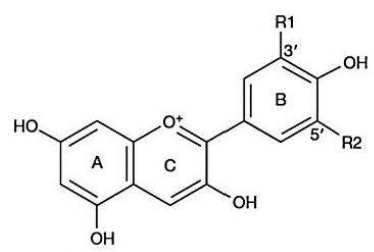

FIG. 8.1 Structure of anthocyanin.

red kidney bean, pea, and black soybean [3-5]. The basic chemical structure of anthocyanin is shown in Fig. 8.1.

\section{LEGUME ANTHOCYANIN AS ANTIOXIDANT}

Legume seeds are included as pulse crops, which belong to the Leguminoceae family. It has been cultivated in many areas and consumed as a staple or complementary food in traditional and modern diets. The nutritional value of legumes has been broadly investigated. Legumes are rich in proteins, fiber, vitamins, amino acids, polypeptides, flavonoids, and phenolic compounds, which are considered as a good ingredient of a functional food formulation. A number of researchers have reported the potentiality of legumes as a good source of antioxidants and also their ability to prevent diseases. The major compounds of legumes responsible for their high antioxidant activity are believed to be the phenolic and flavonoid compounds.

Anthocyanin, which belongs to the flavonoid group, are a natural pigment that is broadly dispensed in plants that are used in the human diet, including fruits, vegetables, and colored legumes [6]. The anthocyanin occurring in legumes appears as a darker color, ranging from red, purple, greenish, blue/gray, to black, in legume seed coats. Anthocyanins in legumes are correlated with a broad range of biological activities, such as antioxidant, anticancer, and antiinflammatory agent. Its mechanism in preventing some diseases through the role of antioxidant has been investigated. Likewise, the effect of food processing on the antioxidant activity of anthocyanin has been examined intensively. Regarding the development of legumes as functional food ingredients, legume anthocyanin's promising ability as an antioxidant is still an interesting topic in recent studies.

\subsection{Black Soybean}

Soybeans (Glycine max L Merril) have been widely used as a food source around the world due to their 
TABLE 8.1 Black Soybean-Based Product

\begin{tabular}{|c|c|c|c|}
\hline Products & Description & $\begin{array}{l}\text { Countries } \\
\text { of } \\
\text { production }\end{array}$ & References \\
\hline Natto & $\begin{array}{l}\text { Fermented soybean paste, } \\
\text { produced through the } \\
\text { fermentation of soy with } \\
\text { Bacillus subtilis }\end{array}$ & Japan & $\begin{array}{l}\text { Park et al. } \\
\text { [11] }\end{array}$ \\
\hline Tofu & $\begin{array}{l}\text { Soybean curd made by } \\
\text { coagulation of heated } \\
\text { soya milk with coagulant, } \\
\text { followed by moulding } \\
\text { and pressing the curd to } \\
\text { draw the whey }\end{array}$ & $\begin{array}{l}\text { Asian } \\
\text { Countries }\end{array}$ & $\begin{array}{l}\text { Gartaula } \\
\text { et al. [12] }\end{array}$ \\
\hline Chunjang & $\begin{array}{l}\text { Black soybean paste, } \\
\text { fermented by Bacillus } \\
\text { species }\end{array}$ & $\begin{array}{l}\text { Korea and } \\
\text { China }\end{array}$ & $\begin{array}{l}\text { Bai et al. } \\
\text { [13] }\end{array}$ \\
\hline Jajang & $\begin{array}{l}\text { Black soybean sauce, } \\
\text { made from fried } \\
\text { chunjang, fermented by } \\
\text { Bacillus species }\end{array}$ & $\begin{array}{l}\text { Korea and } \\
\text { China }\end{array}$ & $\begin{array}{l}\text { Bai et al. } \\
\text { [13] }\end{array}$ \\
\hline Tempeh & $\begin{array}{l}\text { Fermented soybean with } \\
\text { fungus, such as Rhizopus } \\
\text { oligosportus and Rhizopus } \\
\text { oryzae }\end{array}$ & Indonesia & $\begin{array}{l}\text { Chang } \\
\text { et al. [14] }\end{array}$ \\
\hline $\begin{array}{l}\text { Kinema, } \\
\text { peruyyan, } \\
\text { and } \\
\text { hawaijar }\end{array}$ & $\begin{array}{l}\text { Fermented food with } \\
\text { sticky texture, gray tan } \\
\text { color, with slight } \\
\text { ammoniacal flavor } \\
\text { produced by natural } \\
\text { fermentation }\end{array}$ & India & $\begin{array}{l}\text { Tamang } \\
\text { [15] }\end{array}$ \\
\hline
\end{tabular}

various nutrient and functional compounds, such as proteins, lipids, vitamins, fiber, and phytochemicals. Soybeans are popular in China, Japan, Korea, India, and Southeast Asia nations [7]. Particularly in Asia, soybeans are used in the making of soya paste, soya curd, tempeh, tofu, and oil [8]. Soybean consumption's beneficial health effects include prevention of cancer, early aging, diabetes, and cardiovascular disease [9].

One of the soybean varieties is black soybean. Black soybean is commonly consumed as a food ingredient, especially in fermented products. In Korea, black soybean is utilized to make chujang and jajang. Natto is also popular as a black soybean-based fermented food in Japan. In Indonesia, black soybeans are used for the production of tempeh [10]. The utilization of black soybean for food production is presented in Table 8.1.

Recent research shows that black soybean has been found to possess a high amount of anthocyanins along with strong biological activity [16]. Pigmentation of black soybean seed coats is contributed by anthocyanin. Anthocyanins in the black soybean seed coat are reported to have antioxidant activities and abilities for $\alpha$-glucosidase inhibition, regulation of adhesion molecules, protection from ischemia, reperfusion of heart injury, stimulation of wound healing in fibroblasts, and prevention of inflammation in endothelial cells [17]. Anthocyanin may be as essential as isoflavone in determining black soybean characteristics and its functional source. Moreover, the radical scavenging effects of anthocyanin against DPPH and ABTS radicals were stronger than other isoflavones [9].

The anthocyanin compositions are diverse among different black soybean varieties. A study of the correlations between antioxidation and the contents of total phenolics and anthocyanin in 127 accessions of black soybean in China has been reported [18]. Major differences existed among 127 types of accessions, which came from difference geographical regions. The average values of total antioxidant capacity of black soybean were remarkably higher than for yellow soybean, indicating that active material contents of black soybean are apparently superior to yellow soybean, due to its anthocyanin content [19]. Related to anthocyanin content, the best type of black soybean was the autumn sowing type, followed by the summer sowing type and the spring summer type [18]. The anthocyanin content may either be indicated by genetic means or planting conditions and ecological environments.

A recent study showed that nine anthocyanins were found in soluble phenolics that are isolated and identified from the extract of black soybean [9]. Three major anthocyanins, cyanidin-3-glucoside, delphinidine-3-O-glucoside, and petunidin-3-O-glucoside, respectively constitute more than $90 \%$ of the total anthocyanin content, but the predominant anthocyanin in black soybean was cyanidin-3-glucoside [20]. Some animal model studies revealed that cyanidin-3-O-glucoside is the most bioactive anthocyanin in avoiding diabetes and obesity-related diseases [21]. Cyanidin-3-O-glucoside content in the black soybean seed coat ranged from 6.275 to $19.808 \mathrm{mg} / \mathrm{g}$, approximately $75 \%$ to $96 \%$ of total anthocyanin content [9]. Anthocyanin content and composition may be highly influenced by the distinct cultivar, genetics, and environmental stresses, as shown in Table 8.2 [20].

Anthocyanin showed obvious antioxidant capacity in many in vivo and in vitro studies, as shown in Table 8.3. in vitro antioxidant capacity of anthocyanin of black soybean varieties in Indonesia by monitoring TBARS formation has been reported [10]. All of the anthocyanin extracted at various levels from black soybean was effective to inhibit low density lipoprotein (LDL) oxidation. A greater inhibition of LDL oxidation was found through black soybean consumption than for yellow soybean $[26,27]$. The seed coat of black soybean, which contains anthocyanins, was reported to have higher antioxidant activity than the yellow soybean coat. The lag time of LDL oxidation by the black soybean seed coat extract was almost four times longer than the lag time of LDL 
8. ANTIOXIDANT ACTIVITY OF ANTHOCYANINS IN COMMON LEGUME GRAINS

TABLE 8.2 Total Anthocyanin Contents of Different Black Soybean Varieties

\begin{tabular}{|c|c|c|c|}
\hline $\begin{array}{l}\text { Black soybean } \\
\text { varieties }\end{array}$ & $\begin{array}{l}\text { Country } \\
\text { of origin }\end{array}$ & $\begin{array}{l}\text { Total anthocyanin } \\
\text { content }(\mathrm{mg} / \mathrm{g})\end{array}$ & References \\
\hline $\begin{array}{c}\text { Geomjeongkong } 2 \\
\text { Crop year: } 2009 \\
\text { Crop year: } 2010\end{array}$ & Korea & $\begin{array}{l}20.030 \\
23.043\end{array}$ & $\begin{array}{l}\text { Man et al. } \\
\text { [9] }\end{array}$ \\
\hline $\begin{array}{l}\text { Seonheukkong } \\
\text { Crop year: } 2009 \\
\text { Crop year: } 2010\end{array}$ & & $\begin{array}{l}8.885 \\
12.697\end{array}$ & \\
\hline $\begin{array}{l}\text { Cheongja } 2 \\
\text { Crop year: } 2009 \\
\text { Crop year: } 2010\end{array}$ & & $\begin{array}{l}10.948 \\
10.904\end{array}$ & \\
\hline $\begin{array}{l}\text { Cheongja } 3 \\
\text { Crop year: } 2009 \\
\text { Crop year: } 2010\end{array}$ & & $\begin{array}{l}10.894 \\
14.072\end{array}$ & \\
\hline Dongbeichun & China & 0.98 & $\begin{array}{l}\text { Xu et al. } \\
\text { [18] }\end{array}$ \\
\hline Beifangchun & & 0.1 & \\
\hline Nanfangchun & & 0.83 & \\
\hline Nanfangxia & & 0.88 & \\
\hline Malika & Indonesia & 13.6 & $\begin{array}{l}\text { Astadi } \\
\text { et al. [10] }\end{array}$ \\
\hline Cikuray & & 14.5 & \\
\hline
\end{tabular}

oxidation by the yellow soybean seed coat [27]. Total polyphenol content of black soybeans was also higher than the yellow soybeans. The LDL protection of anthocyanin may be due to metal-chelating and radical scavenging capacity, but the mechanism by which the extract inhibits LDL oxidation in vitro remains unclear. Another research study on in vitro antioxidant capacity of anthocyanin has revealed that the multiple carbon ring structure that belongs to anthocyanin, which is similar to cholesterol, has a greater opportunity to protect cholesterol from oxidation. It may potentially contribute to preventing the inflammation related to cardiovascular and other chronic diseases [28].

Fermented black soybean has a higher antioxidant content compared to nonfermented soybeans [22]. Natto, as a fermented product of black soybeans, has fibrinolytic activity due to its nattokinase enzyme. Natto consumption decreased total cholesterol level in hypercholesterolemia rat model serum $[11,22]$. It was also reported to have antithrombotic effects and inhibit coagulation of platelets, which was generated by the increasing of prothrombin time and the euglobulin clot lysis time in rat models fed with 750 and $1500 \mathrm{mg} /$ head/day natto dried powder. There were no statistical differences in antithrombotic effects between those rats fed with natto dried powder and the control group, which received $100 \mathrm{mg} / \mathrm{head} /$
TABLE 8.3 Health Promoting Properties in Several Black Soybean Products

\begin{tabular}{|c|c|c|}
\hline Soybean product & Health promoting properties & References \\
\hline Black soybean natto & $\begin{array}{l}\text { Hypocholesterolemic therapy } \\
\text { for treating the male } \\
\text { reproduction system }\end{array}$ & $\begin{array}{l}\text { Gofur and } \\
\text { Lestari [22] }\end{array}$ \\
\hline $\begin{array}{l}\text { Black soybean seed } \\
\text { coat extract }\end{array}$ & $\begin{array}{l}\text { Anti-inflamatory and antifibrotic } \\
\text { effects on penile plaque } \\
\text { formation in rat peyronie disease } \\
\text { models }\end{array}$ & $\begin{array}{l}\text { Kim et al. } \\
\text { [23] }\end{array}$ \\
\hline $\begin{array}{l}\text { Fermented black } \\
\text { soybean with } \\
\text { Bacillus spp. }\end{array}$ & $\begin{array}{l}\text { Inhibition of Angiotensin } \\
\text { Converting Enzyme (ACE) }\end{array}$ & $\begin{array}{l}\text { Juan et al. } \\
\text { [24] }\end{array}$ \\
\hline $\begin{array}{l}\text { Roasted black } \\
\text { soybean powder }\end{array}$ & $\begin{array}{l}\text { Improve cholesterol metabolism, } \\
\text { insulin resistance, and alleviate } \\
\text { oxidative damage in Non- } \\
\text { Alcoholic Fatty Liver Disease } \\
\text { (NAFLD) }\end{array}$ & $\begin{array}{l}\text { Jung and } \\
\text { Kim [25] }\end{array}$ \\
\hline $\begin{array}{l}\text { Thai Fermented soy } \\
\text { bean (thua nao) }\end{array}$ & $\begin{array}{l}\text { Enhance free radical-scavenging } \\
\text { activity and ferric reducing } \\
\text { antioxidant power, inhibit LDL } \\
\text { oxidation }\end{array}$ & $\begin{array}{l}\text { Dajanta } \\
\text { et al. [26] }\end{array}$ \\
\hline
\end{tabular}

day aspirin. The dried natto powder contains not only nattokinase but also other biologically active compounds. This may confirm that normal dietary intake of natto offers potential health benefits in preventing cardiovascular disease. Moreover, black soybean natto consumption could affect the reproduction system of hypercholesterolemic male mice by increasing the density and motility of sperm and the testosterone level, as compared to a high-fat fed mice group [22].

Another research study on the inhibitory effect of black soybean supplementation on nonalcoholic fatty liver disease (NAFLD) found that black soybean had inhibitory effects on the cholesterol metabolism and insulin resistance of mice receiving a high cholesterol diet (HCD) [25]. Mice receiving black soybean supplementation had lower blood fasting glucose and insulin levels compared to the group of mice that received HCD. Black soybean supplementation also decreased liver total cholesterol and triglyceride levels in mice compared to the HCD group. The alanine aminotransferase (ALT) and aspartate aminotransferase (AST) levels, which were analyzed to evaluate liver function, were significantly increased in the HCD group compared to the normal cholesterol diet (NCD) group, but there were no statistical differences among all the experimental groups receiving black soybean supplementation. The antioxidant activities of black soybean were analyzed using hepatic antioxidative enzyme activities, including SOD, GPx, and catalase. The results found that the SOD, GPx, and catalase activities were significantly decreased in the HCD group and were 
significantly higher in all the experimental groups supplemented with black soybean than in the HCD group. The Malondialdehyde (MDA) and nitrate levels of groups receiving black soybean supplementation was lower than the HCD group, indicating that black soybean could regulate antioxidative enzyme activities in the liver of NAFLD mice. The serum adiponectin, which is involved in insulin resistance in NAFLD, was significantly lower in the HCD group than in the NCD group and largely increased with black soybean supplementation in a dose-dependent manner. Black soybean influences insulin sensitivity and regulation of blood glucose by improving fatty acid oxidation, glucose intake, and insulin resistance via adiponectin secretion. Therefore, black soybean supplementation may have effectively prevented NAFLD, due to its capacity to inhibit fat digestion, fat adsorption, and insulin resistance [25].

\subsection{Common Bean}

Common beans (Phaseolus vulgaris L.), which are extensively consumed throughout the world, play a key role in the traditional human diet. They have been recently developed as a food ingredient in several food products, mainly because of the high content of protein, starch, dietary fiber, micronutrients, and bioactive compounds with low levels of fat [29-31]. The greatest varieties of leguminous plant can be found in tropical and subtropical areas [32]. There are more than 40,000 varieties of common beans in the world. It has one of the highest levels of variation in growth habit, seed characteristics, maturity, and adaptation [33].

Dry beans, the primary product of common beans, are considered to be exceptional commodities related to their long storage life, good nutritional properties, and simple storage for eating. The health benefit of consuming beans has been established in the later epidemiological studies, especially related to the antioxidant capacity, which could be observed by analyzing the amount of anthocyanins, isoflavones, and other polyphenol compounds [34]. Those bioactive components are responsible for the antioxidant activity of common beans. Similar to the black soybean, the seed coat is also responsible for the antioxidant capacity of common beans, as shown in Table 8.4. Determination of color could be a good indicator to predict the antioxidant capacity of beans. The color features of dry kidney bean are related to the anthocyanin content and antioxidant activities of 26 kidney beans cultivated in China [35]. Some individual anthocyanins observed were cyanidin, delphinidin, petunidin, peonidin, pelargonidin, and malvidin. The color feature of bean coat was analyzed using a colorimeter. The results showed that some of the kidney beans with the lighter seed coat color contain smaller anthocyanin content if
TABLE 8.4 Anthocyanin Content From Common Beans Based on Seed Coat Color

\begin{tabular}{lll}
\hline Seed coat color/varieties & $\begin{array}{l}\text { Anthocyanin } \\
\text { content }\end{array}$ & References \\
\hline Cream & $0.055 \%^{a}$ & Diaz et al. [34] \\
Yellow & $0.046 \%^{a}$ & \\
Brown & $0.048 \%^{a}$ & \\
Pink & $0.062 \%^{a}$ & \\
Red & $0.161 \%^{a}$ & \\
Purple & $0.049 \%^{a}$ & Akond et al. [37a] \\
Black & $0.25-0.47 \mathrm{mg} / \mathrm{g}$ & \\
Cream mottled & $0.05-0.16 \mathrm{mg} / \mathrm{g}$ & \\
White & $0.06-0.15 \mathrm{mg} / \mathrm{g}$ & \\
Pink with black spot & $0.16 \mathrm{mg} / \mathrm{g}$ & \\
Light cream & $0.14 \mathrm{mg} / \mathrm{g}$ & \\
\hline a Expressed as delphinidin-3-glucoside equizalents.
\end{tabular}

${ }^{a}$ Expressed as delphinidin-3-glucoside equizalents.

compared to the darker seed coat. There was a strong correlation between the delphinidin content and the seed coat color of kidney bean. The 3-O-glucosides of delphinidin were found to be the major anthocyanin of black beans [34-36]. The total anthocyanin contents in the seed coat ranged from 0 to $5.84 \mathrm{mg} / \mathrm{g}$ and was reported to be higher than some fruits and vegetables with dark color, such as blueberries and red cabbage. The highest total anthocyanin content was found in cultivar Honghuayuanzhongheizibaijia $(5.84 \mathrm{mg} / \mathrm{g})$, followed by the Honghuaheizibaijia $(4.76 \mathrm{mg} / \mathrm{g})$ and Jiuliqing $(4.55 \mathrm{mg} / \mathrm{g})$. The anthocyanin composition reported in common beans varied compared to cowpea [37].

Another legume cultivated in Asia is red adzuki beans (Vigna angularis). This legume was traditionally used for making red bean paste [38]. The adzuki bean seed coat contains a high amount of polyphenols identified as catechin and epicatechin glycosides, quercetin glycosides, myricetin, anthocyanin, and procyanidin dimers [39]. The role of adzuki bean bioactive components in preventing certain diseases has been recently reported. Adzuki bean seed coats (ABSC) treatment on hypertensive rats has attenuated vascular oxidative stress and inflammation in spontaneously hypertensive rats. Polyphenolcontaining adzuki bean seed coats restrained the elevation of rat's systolic blood pressure throughout the treatment period. The $\mathrm{NADPH}^{-}$stimulated $\mathrm{O}_{2}^{-}$level and the NADPH oxidase subunits decreased significantly in the aorta of spontaneously hypertensive rats which were treated by ABSC, compared to the untreated ones, suggesting that $\mathrm{ABSC}$ suppressed excess $\mathrm{O}_{2}^{-}$production in the aorta during progression of hypertension. Thus, ABSC treatment could be useful as a preventive strategy for hypertension and atherosclerosis [40]. 
Food processing has effects on the antioxidant capacity of common beans. The health benefit of common bean consumption depends mainly on their thermal processing [41]. Anthocyanin-containing beans such as black beans, kidney beans, and pinto beans are usually cooked or thermally processed before being consumed. Anthocyanins are sensitive to heat but there was no significant degradation of the total phenolic content of canned and open-pan-cooked black beans compared to crude black beans [41]. However, the total phenolic content was not always related to the antioxidant capacity. Total phenolics and flavonoid content of common beans increased after toasting, rather than boiling or cooking by autoclaving [42]. Thermal processing may release more bound phenolic acids from the breakdown of the cellular constituents. The stability of antioxidant products such as phenolics and flavonoids during heating may be due to the formation of Mailard products, such as hydroxymethylfurfuraldehyde, that also exhibit high antioxidant capacity $[42,43]$. Soaking dry beans before cooking could leads to the softening of wall tissues and increase the solubility of bound polyphenols that may later leach into the soaking water during the process. Nevertheless, the amount of polyphenol compound leach was not significant.

Another processing method that can be used to increase the utilization of common beans as a good source of antioxidants in food production is fermentation. Bacillus subtilis and Lactobacillus plantarum strains were used as microbial agents in solid state and liquid state fermentation using kidney beans var. Pinto [44]. The results indicate that the solid state extract from the fermentation using Bacillus subtilis contains high soluble phenolic compound content $(31-36 \mathrm{mg} / \mathrm{g}$ ) and antioxidant activity (508-541 $\mu \mathrm{g}$ trolox equivalent/g), while liquid state fermentation extract using the Lactobacillus plantarum strain showed potential antihypertensive activity related to high levels of $\gamma$-aminobutiric acid (GABA) and angiotensin converting enzyme inhibitory (ACEI) activity $(90 \%)$. Thus, this revealed that fermented kidney bean var. Pinto can be a good source of bioactive compounds. The fermentation process yields water-soluble functional extract that can be used as functional ingredients in novel foods and neutraceuticals to prevent cardiovascular diseases $[44,45]$.

Despite the antioxidant activity and other health benefits of common beans, there is still limited information on the transformation of those biological components associated with the food matrix during gastrointestinal digestion, especially in the form of a food product. Later studies have simulated the whole digestion process, from mouth to colon, to estimate bioaccessibility and small intestine permeability of free phenolic compounds in a corn cooked-common bean flours chips [46]. The DPPH and ABTS antioxidant capacity of the chips in in vitro gastrointestinal digestion was found higher at the mouth stage in comparison to methanolic extract. As the gastrointestinal digestion progresses, the antioxidant activity increases until reaching the large intestine, where the value decreases. The lowest antioxidant activity reported in the large intestine might be due to some phenolic compounds that cannot cross the epithelial intestine barrier and reach the colon, where colonic microbials ferment them and modify the antioxidant capacity [46,47]. Apparent permeability (Papp coefficient) was also investigated to define the rate of accumulation of a compound in a receptor chamber normalized by superficial tissue area and it has been used as an $e x$ vivo measurement related to human absorption coefficient $[46,48,49]$. They found that the Papp coefficient for phenolics compounds were high, suggesting that the model applied is similar to an in vivo model [46].

Numerous studies on functional bioactive compounds in common beans have focused on the amount of the component, the health benefit in a crude form and in food mixture or food products, and the effects of processing on the antioxidant capacity. However, studies of the in vivo bioavailability and bioaccessibility through gastrointestinal models are still limited. With regard to the importance of such topics, more research related to the bioavailability and bioaccessibility of common bean antioxidant compounds needs to be conducted.

\subsection{Cowpea}

Cowpea (Vigna unguiculata), also known as black-eyed peas, southern peas, and crowder peas is a kind of pulse grain which is the most widely produced pulse grain behind common dry beans (Phaseolus vulgaris) and chickpea (Cicer arietinum) [50,51]. It can grows well in an area which usually usuitable for most other legumes because of its heat and drought tolerance, making cowpea as an environment and climate-change friendly crop. West Africa is the world largest cowpea productions, accounts for more than $87 \%$ of the world production and use. Cowpea were more popular than common legume grains to be used in Africa [52].

Cowpea contains bioactive compounds including polyphenols which are condensed in the seed coat. As in found on soybean and common beans, the composition of phenolics in cowpea varieties are also diverse, mainly be affected by seed coat color. The phenolic compounds are responsible for most of the coloration observed in cowpea varieties, ranging from white, read, cream, bronze, purple, to black $[50,53]$. The seed color, polyphenol structure and composition are directly affects specific mechanism for disease prevention and also influence nutrient bioavailability of cowpea varieties.

The major phenolic compound found in cowpea is the phenolic acids [53]. Red cowpea phenotypes tend to have 
the highest phenolic acids compared to other cowpea varieties. The phenolic content of cowpea was ranging from 19.1 to $48.3 \mathrm{mg} / 100 \mathrm{~g}$ for a set of 15 commonly consumed cowpea varieties, considerably higher than the phenolic content of common dry beans (Phaseolus vulgaris). The phenolic acids are possibly an important contributors to health benefits related to phenols in cowpea and other pulses [50].

Anthocyanin is a bioactive compound that also found in cowpea. It found only in a specific phenotypes, usually in the black pigmented seed $(1.7-3.9 \mathrm{mg} / \mathrm{g})$ and concentrated mostly in the seed coat, showed as more than fivefold relative to the entire seed $[50,54,55]$. Seed coat also contained approximately 10 times more flavonoid compared to whole seeds [56]. Anthocyanin found in black, grey, navy blue, green, and black/grey varieties of cowpea, dominated by delphinidin-3-O-glucoside and cyanidin-3-Oglucoside which account for $68 \%-74 \%$ of all the pigments [37]. Besides delphinidin and cyanidin, other anthocyanins presented in cowpea are petunidin, peonidin, and malvidin, as shown in Table 8.5. Other pigmented red, maroon, and brown seed coat varieties contain no measureable anthocyanins $[6,37]$. Regarding the fact that anthocyanin were concentrated in the seed coat, processing technology that remove the seed coat will unwittingly eliminate the benefit of anthocyanin, as well as removing valuable other phenolic compound and fiber. Similar to common beans, thermal process have limited effect on the profile of phenolic compound. Additional work is needed to uncover the metabolism of bioactive compound in cowpea and their specific properties in order to be able to utilize cowpea in food formulation and products such as snack, cereals, and baked goods with high bioactive compound content and antioxidant activities.

TABLE 8.5 Anthocyanin Composition of Cowpea Seed (Awika and Duodu [50]; Chang and Wong [55]; Ojwang et al. [54])

\begin{tabular}{ll}
\hline Anthocyanin compound & Proportion (\%) \\
\hline Delphinidin-3-O-glucoside & $26-33$ \\
Delphinidin-3-O-galactoside & $8-11$ \\
Cyanidin-3-O-glucoside & $24-27$ \\
Cyanidin-3-O-galactoside & $1-8$ \\
Petunidin-3-O-glucoside & $11-14$ \\
Petunidin-3-O-galactoside & $<2$ \\
Peonidin-3-O-glucoside & $2-3.5$ \\
Peonidin-3-O-malonylglucoside & $<2$ \\
Malvidin-3-O-glucoside & $10-13$ \\
Malvidin-3-O-acetylglucoside & 3 \\
\hline
\end{tabular}

\subsection{Peanut}

Peanuts (Arachis hypogaea) is one of the Leguminoceae family which are rich in oils, protein, vitamins, and other bioactive component such as phenolic compounds [57]. Peanuts was widely consumed across the world due to its unique flavor and flexibility in processing. Peanut can be eaten raw, boiled, roasted, and used in recipes not only in traditional food but also made into modern food ingredient [58]. Recent research shows that peanut was rich in antioxidant, phenolics, and other phytochemicals such as flavonoids, proanthocyanidins, and anthocyanins [58-60]. Those phytochemicals were found having role in preventing cancer, coronary heart diseases, degenerative nerve disease, Alzheimer, and viral/fungal infections [58]. The polyphenols and flavonoid in peanuts were responsible on its antioxidant capacity, antimutagenic capacity, and anti-proliferative effects [60].

Similar to other legumes, seed coat color in peanuts varieties were also rich in antioxidant. Peanut seed coat was varied from colorless/white, red, to deep purple/ black. Seed coats were very light, contributed only $2 \%-$ $7 \%$ of the total kernel weight. However, the total phenolic content (TPC) of seed coats (97.3-133.5 mg GAE/g) was significantly higher compared to raw kernel (3.28-9.20mg GAE/g) and cotyledon $(0.88-1.85 \mathrm{mg}$ $\mathrm{GAE} / \mathrm{g}$ ) for 6 varieties of peanuts found in China [58]. Moreover, seed coats also contributed to the majority of TPC $(67 \%-87 \%)$ presented in raw kernel, while only $12 \%-18 \%$ of TPC is allocated to the cotyledon. The same trend was also found in the total flavonoids content (TFC), condensed tannin content (CTC), monomeric anthocyanin content (MAC), and antioxidant capacity analyzed with DPPH and FRAP, which indicated that seed coats were the major source of antioxidant found in peanuts. Those trends represented in both for the red and the black seed coat peanuts, but the MAC for black seed coat peanuts appeared higher than that observed in red seed coats. The study also revealed that boiling may leads to significant losses in phytochemical contents and the antioxidant capacities of colored-seed coat peanuts.

Regarding the function of peanuts varieties as the source of antioxidant, the seed coat were not the only important one which define the total antioxidant capacity. The colorless peanuts varieties also have potential of being a good source of antioxidant. The antioxidant capacity of peanuts is not always directly related to the intensity of their seed color [60]. The results indicated that the Israeli peanut cultivars that have pale pink seed coat were discovered to have very high TPC, TFC, and FRAP antioxidant capacity, although their Total Anthocyanin Content (TAC) value was not very high. It may cause by the colorless flavonoids which could be the major source of antioxidant activity in colorless-seed coat peanuts and that colored anthocyanins plays only a secondary role. 
Peanut skins have been used as fortificants in developing new food products to improve the content of bioactive compound. The aim of food fortification is to improve the health benefit of food. Peanut skins contains high proanthocyanidin content which have beneficial effect, however it may cause bitterness and astringent mouthfeel. Therefore, the formulation must be taken into account in order to produce food product with acceptable sensory characteristic. Peanut skins have been used as an ingredient for chocolate cookies fortification in order to increase their polyphenol content [61]. Peanut skins was added at $1.3 \%, 1.8 \%$, and $2.5 \%$ to cookies in order to increase their polyphenol content. The result showed that the addition of peanut skins in those three different levels increased the total phenolic content and DPPH scavenging activity of the product by $12 \%-50 \%$ and $67 \%-250 \%$, respectively. The antioxidant evaluation carried out using ABTS radical cation scavenging activity, $\mathrm{H}_{2} \mathrm{O}_{2}$ scavenging activity, and hydroxyl radical scavenging activity indicated similar trend as the DPPH assay. Moreover, the data showed that heating process did not have any destructive effect on either TPC or scavenging activity. However, the heating process did affect the product sensory characteristic due to an unexpected food color that has been developed after heating the polyphenol-rich materials in the cookies. Nevertheless, the color change did not affect the acceptability of the cookies in sensory evaluation since the color underlined the chocolate flavor which added to the cookies in order to mask the bitterness and astringent mouthfeel of the peanut skin.

Another food that could be fortified by peanut skins was peanut butter. The addition of ground peanut skins into peanut butter in certain levels resulted in a concentration-dependent increase in the total phenolic content and antioxidant activity. Adding peanut skins was effectively increased the total phenolic content, antioxidant capacity, and fiber content of the fabricated peanut butters in a concentration-dependent manner, at the same time maintaining the USDA's standard of identity for peanut butter. The sensory evaluation of the peanut skinfortified peanut butters was also greatly acceptable [62].

The positive effects of consuming peanuts and its product, such as peanut oils, peanut flour, and peanut seed coats, are well established. Peanuts have healthy fatty acid profile and being good sources of components that are capable of scavenging free radicals [63]. The finding of recent studies has already shown that peanuts and its by-product can be potentially used as an ingredient in functional food formulations. Improvement of existing product may lead into product diversification of established brand available in the market.

\subsection{Lentils}

Lentils (Lens culinaris L.) is one of the oldest crops cultivated by humans and the most consumed leguminous seeds in the world together with peas (Pisum sativum L.), chickpeas (Cicer arietinum L.) and common beans (Phaseolus vulgaris L.). Lentils are not only contains high amount of macronutrients, such as protein, fatty acids, and carbohydrates, but also contain phytochemicals, such as phenolic acids, flavonols, saponin, phytic acids, and condensed tannin, which can be used as a source of antioxidant [64]. Some studies about lentils have shown that the phenolic contents and antioxidant capacity of lentils was one of the highest among the other leguminoceae family [32,65-67].

Lentils are generally canned or dry-packaged for retail sale or processed into flour $[67,68]$. It used in soups, stews, salads, snacks, and vegetarian dishes. It may also be used as a meat substitute or extender due to their high protein content [68]. Lentils flour can be used as glutenfree ingredient to be added in bread, cake, and baby food formulation. The variety of lentils can be represented by their seed color which ranged from yellow to red-orange, green, tan, brown, and black, as a solid or speckled in color, while the cotyledon is red, yellow, or green. The diversity of lentils phenotype indicated the intricate phytochemical characteristic and bioactivities among lentil varieties $[64,68]$. The color differences between lentils indicated that several pigments such as anthocyanins may be existed in lentils. A research that investigated the anthocyanin content of 11 lentils grown in northern part of USA, showed that the French Green lentil which have greenish brown/yellow seed coat exhibit much higher anthocyanin content $(665.6 \mu \mathrm{g} / \mathrm{g})$ than the Pardina $(157.3 \mu \mathrm{g} / \mathrm{g})$ that have greyish brown/yellow seed coat [30]. The anthocyanin content of the other lentil varieties were undetectable by HPLC, but still had the relatively high content of total flavonoid which reflected in their antioxidant assay [30].

The antioxidant activity were significantly differed amongst the various legume extract [32]. The result proved that lentils had the highest total phenolic content, total antioxidant capacity, DPPH scavenging activity, and total reducing power compared to other legumes (Table 8.6). The total antioxidant capacity, DPPH scavenging activity and total reducing power were positively correlated with total phenolic content. The scavenging effects of the legume extract on the 1,1-diphenyl-2-picryl-hydrazyl radi$\mathrm{cal}$ (DPPH) were shown in Fig. 8.2. Bioactive compounds in lentils that responsible for the high ability to act as antioxidant are the phenolic compounds, including procyanidins $(69 \%)$, flavonols $(17 \%)$, flavanones $(5 \%)$, hydroxybenzoic $(5 \%)$ and hydroxycinnamics acids $(4 \%)$ [67].

Three different parts were recognized in the legume seeds: seed coats or testa, cotyledon, and embryonic axe which represent $10 \%, 89 \%$, and $1 \%$, respectively of the seed content [71]. The cotyledon consists the major supply substances and non-flavonoid compounds, which is primarily proteins and carbohydrates, while in the seed coat or testa are located the majority of flavonoid 
4 LEGUME ANTHOCYANIN AS ANTIOXIDANT

TABLE 8.6 Total Antioxidant Activity of Different Legume Grain

\begin{tabular}{|c|c|c|c|}
\hline $\begin{array}{l}\text { Legume } \\
\text { grain }\end{array}$ & $\begin{array}{l}\text { Total phenolic } \\
\text { content (mg/g) }\end{array}$ & $\begin{array}{l}\text { Total } \\
\text { antioxidant } \\
\text { capacity }\end{array}$ & References \\
\hline Pinto bean & $33.4 \pm 3.0$ & $567 \pm 93 \mathrm{U} / \mathrm{g}$ & Zhao et al. [32] \\
\hline Cowpea & $15.2 \pm 0.7$ & $222 \pm 26 \mathrm{U} / \mathrm{g}$ & \\
\hline $\begin{array}{l}\text { Baby lima } \\
\text { beans }\end{array}$ & $9.5 \pm 1.0$ & $116 \pm 3 \mathrm{U} / \mathrm{g}$ & \\
\hline Lentils & $47.6 \pm 5.3$ & $721 \pm 51 \mathrm{U} / \mathrm{g}$ & \\
\hline Chickpea & $21.9 \pm 2.8$ & $648 \pm 18 \mathrm{U} / \mathrm{g}$ & \\
\hline $\begin{array}{l}\text { Small red } \\
\text { beans }\end{array}$ & $45.7 \pm 1.8$ & $622 \pm 32 \mathrm{U} / \mathrm{g}$ & \\
\hline $\begin{array}{l}\text { Red kidney } \\
\text { beans }\end{array}$ & $27.1 \pm 3.0$ & $516 \pm 61 \mathrm{U} / \mathrm{g}$ & \\
\hline $\begin{array}{l}\text { Black } \\
\text { kidney } \\
\text { beans }\end{array}$ & $32.9 \pm 0.1$ & $601 \pm 12 \mathrm{U} / \mathrm{g}$ & \\
\hline Navy beans & $11.6 \pm 0.01$ & $215 \pm 28 \mathrm{U} / \mathrm{g}$ & \\
\hline $\begin{array}{l}\text { Mung } \\
\text { beans }\end{array}$ & $26.7 \pm 1.4$ & $304 \pm 23 \mathrm{U} / \mathrm{g}$ & \\
\hline Pigeon Pea & 0.73 & $52.1 \%$ & $\begin{array}{l}\text { Uchegbu and } \\
\text { Ishiwu [69] }\end{array}$ \\
\hline Yellow Pea & 3.45 & $\begin{array}{l}10.36 \mu \mathrm{mol} \mathrm{TE} / \\
\mathrm{g}\end{array}$ & Oomah et al. [70] \\
\hline Green Pea & $0.65-0.99$ & $\begin{array}{l}1.73-9.95 \mu \mathrm{mol} \\
\mathrm{TE} / \mathrm{g}\end{array}$ & Xu et al. [18] \\
\hline $\begin{array}{l}\text { Adzuki } \\
\text { beans }\end{array}$ & 90 & $\begin{array}{l}1.76 \mu \mathrm{mol} \\
\text { Trolox } / \mathrm{mg}\end{array}$ & $\begin{array}{l}\text { Amarowicz et al. } \\
\text { [39] }\end{array}$ \\
\hline $\begin{array}{l}\text { Faba beans } \\
\text { (14 } \\
\text { varieties) }\end{array}$ & $16.98-67.47^{a}$ & $\begin{array}{l}0.88 \mu \mathrm{mol} \\
\text { Trolox } / \mathrm{mg}\end{array}$ & $\begin{array}{l}\text { Amarowicz et al. } \\
\text { [39]; Chaieb et al. } \\
\text { [70a] }\end{array}$ \\
\hline
\end{tabular}

${ }^{a}$ Expressed as $m g \mathrm{GAE}$ (Galic Acid Equioalent)/100g dried beans. compounds in lentils. Although the seed coat exhibit only small portion of the total weight of lentils, the seed coat flavonoid, such as cathechins, procyanidin, flavonols, and flavones, are the main source of total phenolic content in the lentil seeds. The cotyledon, which represent a big portion of the total weight of lentils, provide low concentration of phenolic compound, that mainly detected as cinnamic and benzoic compounds.

Antioxidant activity of lentils was positively correlated with their phenolic content [64]. That might be developed as an ingredient of functional foods. Lentils proceeded to form micronized flakes can be a promising ingredient to replace oats in snack bar formulations due to its nutritional benefit [72]. Recent research showed that extrusion processing on lentil flour fiberenriched formulation could increase polyphenol fraction [73]. Extrusion process may hydrolyze polyphenol bounds to fiber and protein which may lead to the increase of antioxidant capacity and bioaccessibility. The antioxidant activities of functional components in food product were depended not only on the level of the bioactive compound, but also the composition of the bioactive compound. The antioxidant activity of extruded flour samples which determined using DPPH assay exhibited higher values than the non-extruded flour samples. Extrusion promoted an increase in soluble fiber, total phenolic, hydroxycinnamic, and hydroxybenzoic acids in the lentil-based, fiber-enriched analyzed flours. The flour can be a good alternative to create a functional food with a balance nutritional and phytochemical composition. Those results confirmed the potential of lentils to be used as functional food ingredients. However, research on the effect of lentils consumption in both raw and processed form in preventing degenerative diseases should be intensified in order to evaluate the beneficial effects of lentil's consumption.
FIG. 8.2 Scavenging activity of the legume extract on the 1,1-diphenyl-2-picryl-hydrazyl radical (DPPH) as measured by Zhao et al. [32].

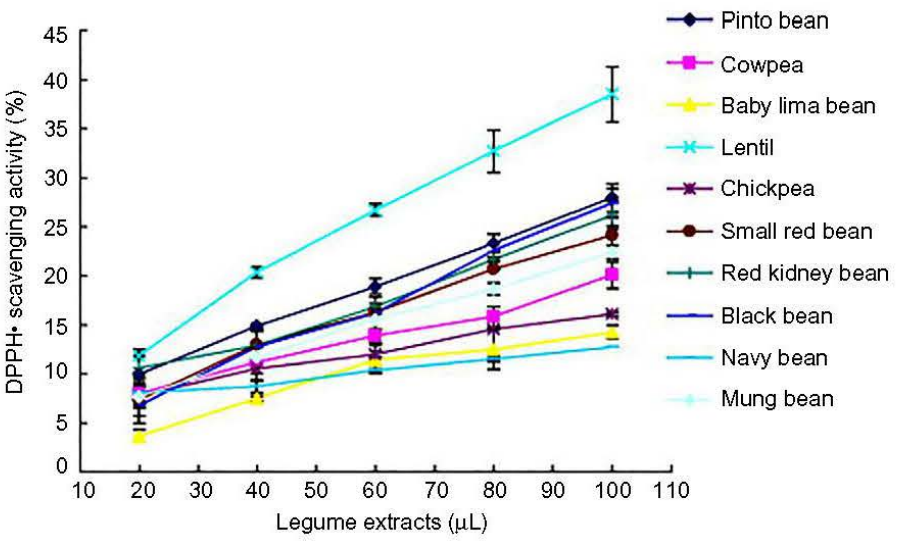




\section{CONCLUSION}

Anthocyanin are predominantly found in the seed coat of dark colored legumes such as black soybean, common bean, cowpea, peanut, and lentils. Among other anthocyanin, cyanidin 3 glucoside is the major anthocyanin found in legumes. Beside the high antioxidant activity, anthocyanin from legumes have been reported exhibit antihypertension, anti-inflammatory, anticarcinogenic, antitumor, and antimutagenic activities. It also enhances spatial memory, enhances cognition, and inhibits LDL oxidation. Increase the consumption of legumes for human daily diet should be recommended due to their beneficial properties for health. Moreover, further research on the application or incorporation of legumes in snacks or other food products in industrial scale should be intensified in order to optimized the intake of anthocyanin and other bioactive compound in legumes.

\section{References}

[1] Kowalczyk E, Baszczyk J. Anthocyanins in medicine. Pol J Pharmacol 2003:55:699-702

[2] Janna OA, Khairul A, Maziah M, Mohd Y. Flower pigment analysis of Melastoma malabathricum. Afr J Biotechnol 2006;5:170-4.

[3] Benninger CW, Hosfield G. Antioxidant activity of extracts, condensed tannin fractions, and pure flavonoids from Phaseolus vulgaris L. seed coat color genotypes. J Agric Food Chem 2003:51:7879-83.

[4] Choung MG, Choi BR, An YN, Chu YH, Cho Y. Anthocyanin profile of Korean cultivated kidney bean (Phaseolus vulgaris L.). J Agric Food Chem 2003;51:7040-3.

[5] Kazuko H, Kazuya H, Akio T. The color of cowpea boiling extract and identification of cowpea peel and cowpea boiling extract anthocyanin pigment. Food Preserv Sci 2003;29:159-63. Studies on the color of sekihan with the Cowpea Part 1.

[6] Ha TJ, Lee MH, Park CH, Pae SB, Shim KBO, Ko JM, et al. Identification and characterization of anthocyanins in Yard-Long beans (Vigna unguiculatassp. sesquipedalis L.) by High-Performance liquid chromatography with diode array detection and electrospray lonization/mass spectrometry (HPLC-DAD-ESI/MS) analysis. J Agric Food Chem 2010;58(4):2571-6.

[7] Huang X, Cai W, Xu B. Kinetic changes of nutrients and antioxidant capacities of germinated soybean (glycine max l.) and mung bean (vigna radiata 1.) with germination time. Food Chem 2014;143:268-76. Available from: https://doi.org/10.1016/j. foodchem.2013.07.080.

[8] Kim EH, Lee OK, Kim JK, Kim SL, Lee J, Kim SH, et al. Isoflavones and anthocyanins analysis in soybean (Glycine max (L.) Merill) from three different planting locations in Korea. Field Crop Res 2014;156:76-83. Available from: https://doi.org/10.1016/j.fcr. 2013.10.020.

[9] Man K, Joung T, Bok Y, Duck W, Young J, Won H, et al. Soluble phenolics and antioxidant properties of soybean (Glycine max L.) cultivars with varying seed coat colours. J Funct Foods 2013;5 (3):1065-76. Available from: https://doi.org/10.1016/j.jff.2013. 03.002 .

[10] Astadi IR, Astuti M, Santoso U, Nugraheni PS. In vitro antioxidant activity of anthocyanins of black soybean seed coat in human low density lipoprotein (LDL). Food Chem 2009;112(3):659-63.
[11] Park KJ, Il KJ, Kim TS, Yeo IH. The antithrombotic and fibrinolytic effect of natto in hypercholesterolemia rats. Prev Nutr Food Sci 2012;17(1):78-82.

[12] Gartaula G, Pokohare S, Ganesh D. Utilisation of lemon juice in the preparation of tofu from black soyabean. J Sci Technol 2013;8:75-7.

[13] Bai X, Byun BY, Mah JH. Formation and destruction of biogenic amines in Chunjang (a black soybean paste) and Jajang (a black soybean sauce). Food Chem 2013;141(2):1026-31. Available from: https://doi.org/10.1016/j.foodchem.2013.03.054.

[14] Chang CT, Hsu CK, Chou ST, Chen YC, Huang FS, Chung YC. Effect of fermentation time on the antioxidant activities of tempeh prepared from fermented soybean using Rhizopus oligosporus. Int J Food Sci Technol 2009;44(4):799-806.

[15] Tamang JP. Naturally fermented ethnic soybean foods of India. J Ethn Foods 2015;2(1):8-17. Available from: https://doi.org/10. 1016/j.jef.2015.02.003.

[16] Correa CR, Li L, Aldini G, Carini M, Oliver Chen CY, Chun HK, et al. Composition and stability of phytochemicals in five varieties of black soybeans (Glycine max). Food Chem 2010;123(4):1176-84 Available from: https://doi.org/10.1016/j.foodchem.2010.05.083.

[17] Wang D, Ma Y, Zhang C, Zhao X. Thermal characterization of the anthocyanins from black soybean (Glycine max L.) exposed to thermogravimetry. LWT Food Sci Technol 2014;55(2):645-9. Available from: https://doi.org/10.1016/j.lwt.2013.10.007.

[18] Xu J-R, Zhang M-W, Liu X-H, Liu Z-X, Zhang R-F, Sun L, et al. Correlation between antioxidation and the content of total phenolics and anthocyanin in black soybean accessions. Agric Sci China 2007:6(2):150-8.

[19] Lee KJ, Lee J, Ma K, Cho Y, Lee G, Chung J. Anthocyanin and isoflavone contents in Korean black soybean landraces and their antioxidant activities. Plant Breed Biotechnol 2016;2016(4):441-52.

[20] Zhang RF, Zhang FX, Zhang MW, Wei ZC, Yang CY, Zhang Y et al. Phenolic composition and antioxidant activity in seed coats of 60 chinese black soybean (Glycine max L. Merr.) varieties. J Agric Food Chem 2011;59(11):5935-44

[21] Wallace TC. Anthocyanins in cardiovascular disease. Adv Nutr 2011;2(7):1-7.

[22] Gofur A, Lestari SR. Effect of black soybean natto extract (Glycine soja) on reproduction system of hypercholesterolemia male mice. Asian Pacific J Reprod 2016;5(5):387-90. Available from: https://doi.org/10.1016/j.apjr.2016.08.002.

[23] Kim SW, Sohn DW, Bae WJ, Kim HS, Kim SW. The Antiinflammatory and antifibrosis effects of anthocyanin extracted from black soybean on a peyronie disease rat model. Urology 2014;84(5):1112-6. Available from: https://doi.org/10.1016/j. urology.2014.06.026.

[24] Juan MY, Wu CH, Chou CC. Fermentation with Bacillus spp. as a bioprocess to enhance anthocyanin content, the angiotensin converting enzyme inhibitory effect, and the reducing activity of black soybeans. Food Microbiol 2010;27(7):918-23. Available from: https://doi.org/10.1016/j.fm.2010.05.009.

[25] Jung J-H, Kim H-S. The inhibitory effect of black soybean on hepatic cholesterol accumulation in high cholesterol and high fat diet-induced non-alcoholic fatty liver disease. Food Chem Toxicol 2013;60:404-12. Available from: http://linkinghub.elsevier.com/ retrieve/pii/S0278691513005036.

[26] Dajanta K, Janpum P, Leksing W. Antioxidant capacities, total phenolics and flavonoids in black and yellow fermented soybean (thua nao). Int Food Res J 2013;20(6):3125-32.

[27] Takahashi R, Ohmori R, Kiyose C, Momiyama Y, Ohsuzu F Kondo K. Antioxidant activities of black and yellow soybeans against low density lipoprotein oxidation. J Agric Food Chem 2005;53(11):4578-82.

[28] Zhang X, Shen Y, Prinyawiwatkul W, King JM, Xu Z. Comparison of the activities of hydrophilic anthocyanins and lipophilic tocols in 
black rice bran against lipid oxidation. Food Chem 2013;141 (1):111-6. Available from: https://doi.org/10.1016/j.foodchem. 2013.03.034.

[29] Chen PX, Tang Y, Marcone MF, Pauls PK, Zhang B. Characterization of free, conjugated and bound phenolics and lipophilic antioxidants in regular- and non-darkening cranberry beans (Phaseolus vulgaris L.). Guelph Food Research Center, Agriculture and AgriFood Canada, 93 Stone Road West, Department of Food Science, Ontario Agricultural College, University of Guelph, Guelph, State Key Laboratory of Food Science and Technology, Nanchang UniversityFood Chem 2015; Available from: https://doi.org/10. 1016/j.foodchem.2015.03.100.

[30] Xu B, Chang SKC. Comparative study on antiproliferation properties and cellular antioxidant activities of commonly consumed food legumes against nine human cancer cell lines. Food Chem 2012;134 (3):1287-96. Available from: https://doi.org/10.1016/j.foodchem. 2012.02.212.

[31] Vadivel V, Stuetz W, Scherbaum V, Biesalski HK. Total free phenolic content and health relevant functionality of Indian wild legume grains: effect of indigenous processing methods. J Food Compos Anal 2011;24(7):935-43. Available from: https://doi.org/10. 1016/j.jfca.2011.04.001.

[32] Zhao $Y$, Du S, Wang H, Cai M. In vitro antioxidant activity of extracts from common legumes. Food Chem 2014;152:462-6. Available from: http://linkinghub.elsevier.com/retrieve/pii/ S030881461301861X.

[33] FAO. Phaseolus bean-post-harvest operations. 1999; 25 p. Available from: http://www.fao.org/3/a-av015e.pdf.

[34] Díaz AM, Caldas GV, Blair MW. Concentrations of condensed tannins and anthocyanins in common bean seed coats. Food Res Int 2010;43(2):595-601. Available from: https://doi.org/10.1016/ j.foodres.2009.07.014.

[35] Kan L, Nie S, Hu J, Liu Z, Xie M. Antioxidant activities and anthocyanins composition of seed coats from twenty-six kidney bean cultivars. J Funct Foods 2016;26:622-31. Available from: https://doi. org/10.1016/j.jff.2016.08.030.

[36] Lin L-Z, Harnly JM, Pastor-Corrales MS, Luthria DL. The polyphenolic profiles of common bean (Phaseolus vulgaris L.). Food Chem 2008;107(1):399-410. Available from: http://linkinghub.elsevier. $\mathrm{com} /$ retrieve/pii/S0308814607008308.

[37] Ojwang LO, Yang L, Dykes L, Awika J. Proanthocyanidin profile of cowpea (Vigna unguiculata) reveals catechin-O-glucoside as the dominant compound. Food Chem 2013;139(1-4):35-43. Available from: https://doi.org/10.1016/j.foodchem.2013.01.117.

[37a] Akond ASMGM, Khandaker L, Berthold J, Gates L, Peters K, Delong H, Hossain K. Anthocyanin, total polyphenols and antioxidant activity of common bean. Am J Food Technol 2011;6(5):385-94.

[38] Han KH, Kitano-Okada T, Seo JM, Kim SJ, Sasaki K, Shimada K, et al. Characterisation of anthocyanins and proanthocyanidins of adzuki bean extracts and their antioxidant activity. J Funct Foods 2015;14:692-701. Available from: https://doi.org/10.1016/j.jff. 2015.02.018.

[39] Amarowicz R, Estrella I, Hernández T, Troszyńska A. Antioxidant activity of extract of adzuki bean and its fractions. J Food Lipids 2008;15(1):119-36.

[40] Mukai Y, Sato S. Polyphenol-containing azuki bean (Vigna angularis) seed coats attenuate vascular oxidative stress and inflammation in spontaneously hypertensive rats. J Nutr Biochem 2011;22 (1):16-21. Available from: https://doi.org/10.1016/j.jnutbio. 2009.11.004.

[41] Rocha-Guzman NE, Gallegos-Infante JA, Gonzales-Laredo RF, Cardoza-Cervantes V, Reynoso-Camacho R, Ramos-Gomez M, Garcia-Gasca T, De Anda Salazar A. Evaluation of culinary quality and antioxidant capacity for Mexican common beans (Phaseolus vulgaris L.) canned in pilot plant. Int Food Res J 2013;20(3):1087-93.
[42] Boateng J, Verghese M, Walker LT, Ogutu S. Effect of processing on antioxidant contents in selected dry beans (Phaseolus spp. L.). LWT Food Sci Technol 2008;41(9):1541-7.

[43] Siddhuraju P. The antioxidant activity and free radical-scavenging capacity of phenolics of raw and dry heated moth bean (Vigna aconitifolia) (Jacq.) Marechal seed extracts. Food Chem 2006;99(1):149-57.

[44] Limón RI, Peñas E, Torino MI, Martínez-Villaluenga C, Dueñas M, Frias J. Fermentation enhances the content of bioactive compounds in kidney bean extracts. Food Chem 2015;172:343-52. Available from: https://doi.org/10.1016/j.foodchem.2014.09.084.

[45] López A, El-Naggar T, Dueñas M, Ortega $T$, Estrella I, Hernández $\mathrm{T}$, et al. Effect of cooking and germination on phenolic composition and biological properties of dark beans (Phaseolus vulgaris L.). Food Chem 2013;138(1):547-55.

[46] Luzardo-Ocampo I Campos-Vega R, Gaytán-Martínez M, Preciado-Ortiz R, Mendoza S, Loarca-Piña G. Bioaccessibility and antioxidant activity of free phenolic compounds and oligosaccharides from corn (Zea mays L.) and common bean (Phaseolus vulgaris L.) chips during in vitro gastrointestinal digestion and simulated colonic fermentation. Food Res Int 2017;100:304-11. Available from: https://doi.org/10.1016/j.foodres.2017.07.018.

[47] Saura-Calixto F, Serrano J, Goñi I. Intake and bioaccessibility of total polyphenols in a whole diet. Food Chem 2007;101(2):492-501.

[48] Volpe DA. Application of method suitability for drug permeability classification. AAPS J 2010;12(4):670-8. Available from: http:// www.springerlink.com/index/10.1208/s12248-010-9227-8.

[49] Palumbo P, Picchini U, Beck B, Van Gelder J, Delbar N, DeGaetano A. A general approach to the apparent permeability index. J Pharmacokinet Pharmacodyn 2008;35(2):235-48.

[50] Awika JM, Duodu KG. Bioactive polyphenols and peptides in cowpea (Vigna unguiculata) and their health promoting properties: a review. J Funct Foods 2017;38:686-97. Available from:https:// doi.org/10.1016/j.jff.2016.12.002.

[51] Jati IRAP, Vadivel V, Biesalski HK. Antioxidant activity of anthocyanins in common legume grains. In: Bioactive food as dietary interventions for liver and gastrointestinal disease. 1st ed. Elsevier Inc.; 2013. p. 485-97. Available from: https://doi.org/10.1016/ B978-0-12-397154-8.00007-5.

[52] Wang Q. Peanuts: processing technology and product development. Academic Press; 2016.

[53] Nderitu AM, Dykes L, Awika JM, Minnaar A, Duodu KG. Phenolic composition and inhibitory effect against oxidative DNA damage of cooked cowpeas as affected by simulated in vitro gastrointestinal digestion. Food Chem 2013;141(3):1763-71. Available from: https://doi.org/10.1016/j.foodchem.2013.05.001.

[54] Ojwang LO, Dykes L, Awika JM. Ultra performance liquid chromatography-tandem quadrupole mass spectrometry profiling of anthocyanins and flavonols in cowpea (Vigna unguiculata) of varying genotypes. J Agric Food Chem 2012;60(14):3735-44.

[55] Chang Q, Wong YS. Identification of flavonoids in Hakmeitau beans (Vigna sinensis) by high-performance liquid chromatography-electrospray mass spectrometry (LC-ESI/MS). J Agric Food Chem 2004;52(22):6694-9.

[56] Gutiérrez-Uribe JA, Romo-Lopez I, Serna-Saldívar SO. Phenolic composition and mammary cancer cell inhibition of extracts of whole cowpeas (Vigna unguiculata) and its anatomical parts. J Funct Foods 2011;3(4):290-7.

[57] do Valle Calomeni A, de Souza VB, Tulini FL, Thomazini M, Ostroschi LC, de Alencar SM, et al. Characterization of antioxidant and antimicrobial properties of spray-dried extracts from peanut skins. Food Bioprod Process 2017;105:215-23. Available from: http://linkinghub.elsevier.com/retrieve/pii/S0960308517300974.

[58] Attree R, Du B, Xu B. Distribution of phenolic compounds in seed coat and cotyledon, and their contribution to antioxidant capacities of red and black seed coat peanuts (Arachis hypogaea L.). Ind Crop 
Prod 2015;67:448-56. Available from: https://doi.org/10.1016/ j.indcrop. 2015.01.080.

[59] Bolling BW, McKay DL, Blumberg JB. The phytochemical composition and antioxidant actions of tree nuts. Asia Pac J Clin Nutr 2010;19(1):117-23.

[60] Shem-Tov Y, Badani H, Segev A, Hedvat I, Galili S, Hovav R. Determination of total polyphenol, flavonoid and anthocyanin contents and antioxidant cap acities of skins from peanut (Arachis hypogaea) lines with different skin colors. J Food Biochem 2012;36(3):301-8.

[61] De CAC, Maldonado C, Vidal M, Canniatti-brazaca SG, Shahidi F. Forti fi cation of cookies with peanut skins: effects on the composition, polyphenols, antioxidant properties, and sensory quality. Agric Food Chem 2014;62:11228-35.

[62] Ma Y, Kerr WL, Swanson RB, Hargrove JL, Pegg RB. Peanut skinsfortified peanut butters: effect of processing on the phenolics content, fibre content and antioxidant activity. Food Chem 2014;145:883-91. Available from: https://doi.org/10.1016/j. foodchem.2013.08.125.

[63] Davis JP, Dean LL, Price KM, Sanders TH. Roast effects on the hydrophilic and lipophilic antioxidant capacities of peanut flours, blanched peanut seed and peanut skins. Food Chem 2010;119(2):539-47. Available from: https://doi.org/10.1016/j.foodchem.2009.06.057.

[64] Zou Y, Chang SKC, Gu Y, Qian SY. Antioxidant activity and phenolic compositions of lentil (Lens culinaris var. Morton) extract and its fractions. J Agric Food Chem 2011;59(6):2268-76

[65] 囚wieca M, Gawlik-Dziki U, Kowalczyk D, Złotek U. Impact of germination time and type of illumination on the antioxidant compounds and antioxidant capacity of Lens culinaris sprouts. Sci Hortic (Amsterdam) 2012;140:87-95.

[66] Singh B, Singh JP, Kaur A, Singh N. Phenolic composition and antioxidant potential of grain legume seeds: a review. Food Res Int 2017;101:1-16. Available from: https://doi.org/10.1016/ j.foodres.2017.09.026.
[67] Aguilera Y, Estrella I, Benitez V, Esteban RM, Martín-Cabrejas MA. Bioactive phenolic compounds and functional properties of dehydrated bean flours. Food Res Int 2011;44(3):774-80. Available from: https:// doi.org/10.1016/j.foodres.2011.01.004.

[68] Xu B, Chang SKC. Reduction of antiproliferative capacities, cellbased antioxidant capacities and phytochemical contents of common beans and soybeans upon thermal processing. Food Chem 2011;129(3):974-81. Available from: https://doi.org/10.1016/ j.foodchem.2011.05.057.

[69] Uchegbu NN, Ishiwu CN. Germinated Pigeon Pea (Cajanus cajan): a novel diet for lowering oxidative stress and hyperglycemia. Food Sci Nutr 2016;4(5):772-7.

[70] Oomah BD, Caspar F, Malcolmson LJ, Bellido AS. Phenolics and antioxidant activity of lentil and pea hulls. Food Res Int 2011;44 (1):436-41. Available from: https://doi.org/10.1016/j.foodres. 2010.09.027.

[70a] Chaieb N, González JL, López-Mesas M, Bouslama M, Valiente M. Polyphenols content and antioxidant capacity of thirteen faba bean (Vicia faba L.) genotypes cultivated in Tunisia. Food Res Int 2011;44(4):970-7. https://doi.org/10.1016/ j.foodres.2011.02.026.

[71] Dueñas M, Hernández T, Estrella I. Phenolic composition of the cotyledon and the seed coat of lentils (Lens culinaris L.). Eur Food Res Technol 2002;215(6):478-83.

[72] Ryland D, Vaisey-Genser M, Arntfield SD, Malcolmson LJ. Development of a nutritious acceptable snack bar using micronized flaked lentils. Food Res Int 2010;43(2):642-9. Available from: https://doi.org/10.1016/j.foodres.2009.07.032

[73] Morales P, Cebadera-Miranda L, Cámara RM, Reis FS, Barros L, Berrios JDJ, et al. Lentil flour formulations to develop new snack-type products by extrusion processing: phytochemicals and antioxidant capacity. J Funct Foods 2015;19:537-44. Available from: https://doi.org/10.1016/j.jff.2015.09.044. 